\title{
Orofaciodigital syndrome type 10
}

INSERM

\section{Source}

INSERM. (1999). Orphanet: an online rare disease and orphan drug data base.

Orofaciodigital syndrome type 10. ORPHA:2756

Oral-facial-digital syndrome, type 10 is characterized by facial (telecanthus, flat nasal bridge, retrognathia), oral (cleft palate, vestibular frenula) and digital (oligodactyly, preaxial polydactyly) features, associated with remarkable radial shortening, fibular agenesis and coalescence of tarsal bones. The syndrome has been described in one 10month-old girl. No new cases have been described since 1993. 